\title{
Performance Evaluation of Collard Based Bio-Filter for Treating Fish Tank Effluent for Re-use
}

Obeti Grism Lawrence $^{1,2}$, Joshua Wanyama ${ }^{3}$, Noble Banadda ${ }^{3,4}$, Alphonse Candia ${ }^{2}$, Samuel George Onep ${ }^{2}$ and Ronald Walozi ${ }^{2}$

1. Department of Agricultural Mechanization \& Irrigation Engineering, Busitema University, Tororo 236, Uganda

2. Agricultural Engineering and Appropriate Research Center, National Agricultural Research Organization, Kampala 7144, Uganda

3. Department of Agricultural and Biosystems Engineering, College of Agricultural and Environmental Sciences, Makerere University, Kampala 7062, Uganda

4. Department of Agricultural and Biosystems Engineering, Iowa State University, 1340 Elings Hall, Ames, Iowa 50011-3270, USA

\begin{abstract}
The increasing Uganda's urban population growth has led to limited space coupled with high cost of living, thus making it difficult for the urban poor in congested areas to afford fish protein hence poor nutrition among the low income earners. Therefore this study was conducted to evaluate the performance of collard based bio-filtration system for filtering fish tank effluent for re-use in congested peri-urban areas. Field physical-chemical parameters (ammonia, nitrate, dissolved oxygen, temperature and $\mathrm{pH}$ ) were measured at various bio-filter lengths in the effluent from both collard based and GBF (Gravel Based Bio-Filter). Differences in mean ammonia and nitrate levels at various lengths were analyzed using one-way ANOVA at $p=0.05$. Ammonia levels were significantly reduced $(p<0.05)$ at various lengths: $\mathrm{L}_{0} 99.1 \mathrm{mg} / \mathrm{L} ; \mathrm{L}_{1} 75.8 \mathrm{mg} / \mathrm{L}(23.6 \%) ; \mathrm{L}_{2} 53.1 \mathrm{mg} / \mathrm{L}(46.4 \%) ; \mathrm{L}_{3} 25.8 \mathrm{mg} / \mathrm{L}(74 \%)$ and $\mathrm{L}_{4} 6.6 \mathrm{mg} / \mathrm{L}$ (93.4\%). Similarly, nitrate levels significantly reduced $(p<0.05): \mathrm{L}_{0} 11.8 \mathrm{mg} / \mathrm{L} ; \mathrm{L}_{1} 7.2 \mathrm{mg} / \mathrm{L}(39.4 \%) ; \mathrm{L}_{2} 3.6 \mathrm{mg} / \mathrm{L}$ (69.2\%); $\mathrm{L}_{3} 1.6 \mathrm{mg} / \mathrm{L}(86.7 \%)$ and $\mathrm{L}_{4} 0.1 \mathrm{mg} / \mathrm{L}(99.3 \%)$. Significant difference $(p<0.05)$ was obtained in mean ammonia and nitrate removal between collard based and gravel bio-filters. Collard based filter yielded higher ammonia and nitrate removal at $\mathrm{L}_{4}$ by $18.3 \%$ and $39.5 \%$ respectively, hence $\mathrm{L}_{4}$ is the effective length for collard based bio-filter.
\end{abstract}

Key words: Effluent, bio-filter, nitrifying bacteria, ammonia.

\section{Introduction}

Globally, the scarcity of fresh water has contributed to increase in reuse of treated effluent in agriculture over the last few decades [1]. Rapid expansion of fish farming due to high demand for fish protein mainly in peri-urban areas has prompted the need for techniques for effective fish effluent treatment for reuse [2]. Fish effluent is poor quality water from fish farm mainly polluted with ammonia, phosphorus and solid matter which becomes toxic to fish [2]. Open disposal of fish effluent not only resulted into environmental pollution, but also restricted future

Corresponding author: Obeti Grism Lawrence, M.Sc., assistant lecturer, research fields: post-harvest, environmental waste management and agricultural machinery. growth and sustainability of fish farming [3]. Sustainable water use in fish farming could be achieved using technologies for proper effluent treatment [4]. Fish effluent treatment has been successful in most developed countries through various bio-filtration methods: conventional methods (nutrient film technique, drip system recovery, trickling filters, rotating biological contactors) and non-conventional methods i.e. constructed wetlands [5]. Despite higher ammonia removal efficiency (80-99\%) by conventional bio-filtration methods than non-conventional (80-90\%), their wider use has been hindered by higher initial, operational and maintenance costs [5]. Integration of fish farming with bio-filtration system for fish effluent treatment makes it a sustainable venture. 
Despite the efforts by Uganda Government in promoting fish farming, high nutrient levels (ammonia $>0.3 \mathrm{mg} / \mathrm{L}$ and nitrate $>200 \mathrm{mg} / \mathrm{L}$ ) in fish ponds render water toxic to fish [6], thus hindering fish growth and limiting reuse of fish effluent. This further resulted into lack of access to high value fish protein especially for the urban poor living in crowded areas. High ammonia and nitrate levels in fish ponds could be lowered by oxidizing ammonia to nitrate and using green leafy vegetables with fibrous roots (collards) to absorb nitrate (bio-filtration). Appropriate size of bio-filtration systems that not only serve as bio-filters but also have additional benefits could be used to reduce ammonia levels. However, there is limited information on the appropriate length and performance of VBF (Vegetable Based Bio-Filter) utilizing indigenous vegetables. It is against this background that the main objective of the study was to evaluate the performance of collard based bio-filtration system in filtering fish tank effluent for reuse in congested peri-urban areas. Collard is one of the green leafy vegetables with fibrous root system which has high potential to absorb nitrogen when planted on soilless media (gravel) through which effluent flows. Also collard is highly demanded in the local markets since it is widely consumed and has short maturity period of 60 days.

\section{Materials and Methods}

\subsection{Study Area}

The study was conducted on a fish farm located at $00.39342^{\circ} \mathrm{N}, \quad 032.47250^{\circ}$ E Mpuga village Wakiso-Uganda). The fish tank effluent used in the study was obtained from one cubic meter fish tank containing 60 African cat fish at six months old, mainly fed on floating pellet feeds locally manufactured. Average length of the fish was $28.4 \mathrm{~cm}$ and body mass of $0.55 \mathrm{~kg}$, generating effluent of concentration $30 \mathrm{mg} / \mathrm{L}$ of ammonia daily.

\subsection{Experimental Layout and Design}

Fish tank effluent treatment system (Fig. 1) has three major parts namely, effluent reservoir (1), vegetable (collard) based bio-filter (4 to 9) and treated effluent tank, $0.12 \mathrm{~m}^{3}$ (11). The fish tank was equipped with effluent distribution pipe to convey effluent into bio-filtration system through $12.7 \mathrm{~mm}$ flexible hose pipes. Fig. 1 shows the design of fish tank effluent treatment system.

In this study, VBF and GBF (Gravel Based Bio-Filter) were used. Both systems utilized gravel bed to provide surface area for microbial loading. However the difference between the two is the vegetables planted on the gravel to form VBF. Fig. 2 below shows the entire experimental layout.

A completely randomized experimental design having three replicates $\left(\mathrm{R}_{1}, \mathrm{R}_{2}\right.$ and $\left.\mathrm{R}_{3}\right)$ and one treatment (length) was used for both collard based and gravel bio-filters. Four levels of length: $\mathrm{L}_{1}(0.6 \mathrm{~m}), \mathrm{L}_{2}$ $(1.2 \mathrm{~m}), \mathrm{L}_{3}(1.8 \mathrm{~m})$ and $\mathrm{L}_{4}(2.4 \mathrm{~m})$ were used. Since the key idea in the study was optimization of bio-filter length and length was varied downstream: $\mathrm{L}_{1}(0.6 \mathrm{~m})$, $\mathrm{L}_{2}(1.2 \mathrm{~m}), \mathrm{L}_{3}(1.8 \mathrm{~m})$ and $\mathrm{L}_{4}(2.4 \mathrm{~m})$. Therefore, effluent at bio-filter inlet $\left(\mathrm{L}_{0}=0 \mathrm{~m}\right)$ taken as control.

\subsection{Design and Construction of Collard based Bio-Filter}

\subsubsection{Design Considerations}

The design considered calculated ammonia loading $(\mathrm{mg} / \mathrm{L})$ in the effluent to determine the bio-filter surface area. Maximum ammonia loading occurs towards fish maturity when amount of fish feed fed ranges from $1.5 \%$ to $3.0 \%$ of body weight per day [7]. Ammonia excreted by fish was considered directly proportional to the amount of feed supplied, $1 \mathrm{~kg}$ feed produces $0.03 \mathrm{~kg}$ of ammonia [7]. Effluent from African cat fish was used and cat fish was considered mature at $500 \mathrm{~g}$ body weight within six months [8].

\subsubsection{Maximum Ammonia Loading}

Daily maximum quantity of feed at a rate $3 \%$ of body weight was calculated using Eq. (1).

$$
\beta=\mathrm{M} \times 0.03
$$

where $\beta$ : total mass of feed given daily $(\mathrm{kg}) ; M$ : total mass of fish towards harvest $(\mathrm{kg})$. 


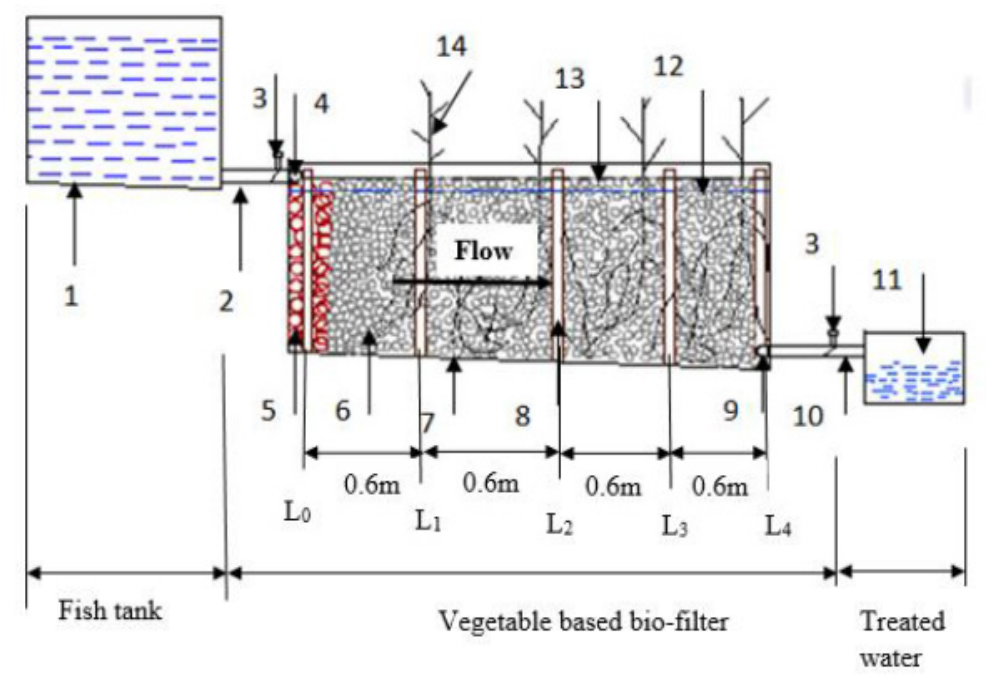

Fig. 1 Fish tank effluent treatment system.

1-effluent reservoir (fish tank), 2-bio-filter inlet pipe, 3-flow regulators, 4-effluent distribution pipe, 5-distribution zone (coarse gravel), 6-fine gravel, 7-impermeable layer 8-vertcal perforated pipes 9-effluent collection pipe (perforated), 10 - effluent exit pipe, 11 - treated water, 12 —effluent surface, 13-gravel surface, 14—vegetables (collards).

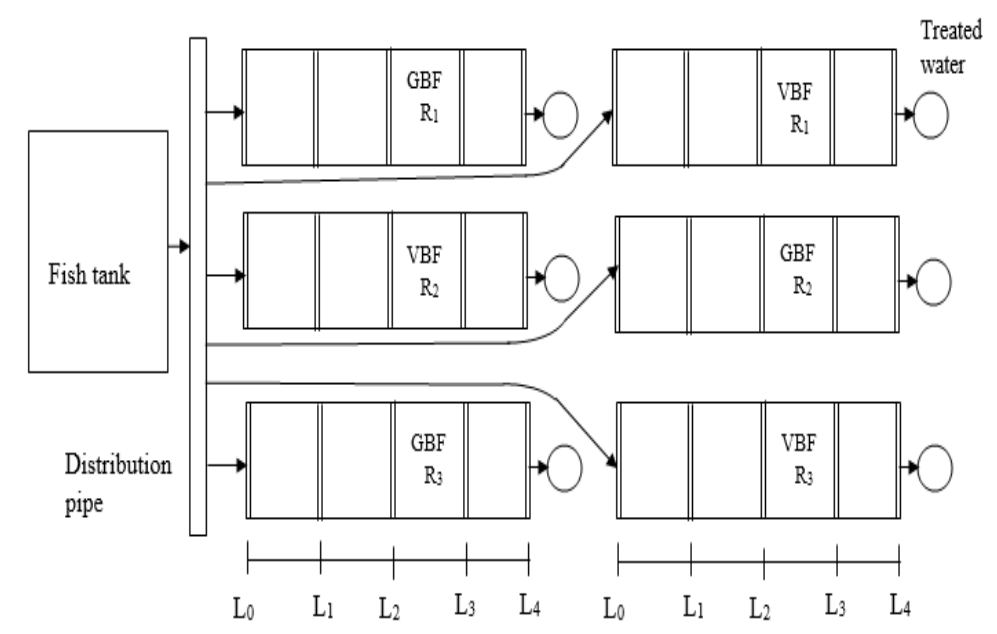

Fig. 2 Experimental layout for fish tank effluent treatment.

1 -effluent reservoir (fish tank), 2-effluent distribution pipe, 3 - treated water.

Maximum daily ammonia loading in 900 liters of water was obtained using Eq. (2).

$$
\alpha=\beta \times 0.03
$$

where, $\alpha$ : maximum daily ammonia loading ( $\mathrm{kg} /$ day).

Therefore, daily ammonia concentration in water $(\mathrm{mg} / \mathrm{L})$ was calculated using Eq. (3).

$$
\lambda=\frac{\alpha \times\left(1 \times 10^{6}\right)}{900}
$$

where $\lambda$ : ammonia concentration in water $(\mathrm{mg} / \mathrm{L})$.

Since the fish farmer was discharging effluent after every 3 to 4 days, maximum ammonia concentration in the effluent at the time of discharge was:

$$
\mu=\left[\lambda \times\left(\frac{3+4}{2}\right)\right] \mathrm{mg} / \mathrm{L}
$$

where $\mu$ : maximum ammonia concentration $(\mathrm{mg} / \mathrm{L})$ in the effluent during discharge.

\subsubsection{Flow Rate through the Filter Bed}

According to Hochheimer and Wheaton [7], hydraulic loading rate of $50 \mathrm{~m}^{3} \mathrm{~m}^{-2} \cdot \mathrm{d}^{-1}$ is considered safe, and United States Environmental Protection Agency [9] suggested that hydraulic gradient of $0.5-1 \%$ is suitable for subsurface flow constructed wetlands. 
Using Darcy's Law, flow rate through the gravel bed ( $Q \mathrm{~m}^{3} /$ day) was calculated using Eq. (4).

$$
Q=k_{s} \times \mathrm{A}_{c} \times S .
$$

where,

$Q:$ Flow rate $\left(\mathrm{m}^{3} /\right.$ day $)$ through the filter bed;

$k_{s}$ : hydraulic conductivity; flow rate per unit cross sectional area perpendicular to flow direction, taken as $50 \mathrm{~m}^{3} \cdot \mathrm{m}^{-2} \cdot \mathrm{d}^{-1}$

$A_{c}$ : Cross sectional area perpendicular to flow $\left(\mathrm{m}^{2}\right)$;

$S$ : hydraulic gradient of bio-filter bed.

But $\mathrm{A}_{c}=W \times d$

$W=$ width of the bed, fixed to $2.4 \mathrm{~m}$;

$d=0.16 \mathrm{~m}$, depth of the bed (collard root depth).

\subsubsection{Bio-Filter Surface Area}

According to [10] general empirical design equation for kinetic design of sub-surface flow constructed wetlands is used for estimating the surface area of bio-filter required to remove ammonia:

$$
\mathrm{A}_{s}=Q\left[\ln \left(\frac{\mathrm{C}_{\mathrm{o}}}{\mathrm{C}_{\mathrm{t}}}\right)\right] \times\left(\frac{1}{k_{T} \times d \times n}\right) .
$$

where,

$$
A_{s}=\text { bio-filter surface area }\left(\mathrm{m}^{2}\right) \text {; }
$$

$Q=$ flow rate $\left(\mathrm{m}^{3} / \mathrm{s}\right)$;

$C_{0}=$ effluent ammonia concentration $(\mathrm{mg} / \mathrm{L})$;

$C_{t}=$ desired ammonia concentration $(\mathrm{mg} / \mathrm{L})$;

$n=$ porosity of gravel bed $=0.38$;

$k_{T}=$ temperature dependant rate constant $\left(\mathrm{d}^{-1}\right)$.

$$
k_{T}=k_{20} \times \theta^{(T-20)}
$$

$k_{20}=$ first order rate constant (nitrification rate constant) at $20{ }^{\circ} \mathrm{C}\left(\mathrm{d}^{-1}\right)$;

$\theta=$ temperature coefficient for the rate constant;

$T=$ effluent temperature $\left({ }^{\circ} \mathrm{C}\right)$.

But $\mathrm{A}_{s}=L \times W$

$L=$ length of bio-filter parallel to flow (m);

$W=$ width of bio-filter, fixed to $(0.8 \mathrm{~m})$.

The overall dimensions of the bio-filter bed $=2.4 \mathrm{~m}$ $\times 0.8 \mathrm{~m} \times 0.16 \mathrm{~m}$ and the flow rate of effluent used in the experimental units was $0.048 \mathrm{~m}^{3} /$ day.

\subsubsection{Material Selection of Pipes}

Flexible PVC (Polyvinyl Chloride) pipe was used for conveying effluent from the tank to the bio-filter units. Such material is light in weight, relatively low price, resistant to corrosion, stable in acidic \& alkalis solutions and also has high hardness. For gravity flow systems in closed pipes, Darcy weisbach Eq. (6) for head loss was used to determine the diameter of the pipe.

$$
h_{l}=f\left(\frac{L}{D} \times \frac{V^{2}}{2 g}\right)
$$

where: $h_{1}=$ head of pressure drop;

$f=$ Darcy friction factor;

$L=$ length of the pipe;

$D=$ pipe diameter $(\mathrm{m})$;

$V=$ mean flow velocity $(\mathrm{m} / \mathrm{s})$.

2.3.6 HRT (Hydraulic Residence Time)

HRT for the effluent in the filter was determined using Eq. (7) [10].

$$
t=\frac{L W n d}{Q} .
$$

where: $t=$ HRT (days).

The width was fixed at $0.8 \mathrm{~m}$ and length varied from $\mathrm{L}_{0}(0 \mathrm{~m}), \mathrm{L}_{1}(0.6 \mathrm{~m}), \mathrm{L}_{2}(1.2 \mathrm{~m}), \mathrm{L}_{3}(1.8 \mathrm{~m})$ and $\mathrm{L}_{4}(2.4 \mathrm{~m})$ downstream. At each of the five lengths, HRT was varied as: $L_{0}, 0$ days; $L_{1}, 0.6$ days; $L_{2}, 1.2$ days; $\mathrm{L}_{3}, 1.8$ days and $\mathrm{L}_{4}, 2.4$ days.

\subsubsection{Construction of Collard Based Filter}

VBF was constructed using wooden poles and timber to form a rectangular tank lined with LDPE (Low Density Polythene) sheet of thickness $1 \mathrm{~mm}$ (Fig. 3). The tank was filled with gravel to a depth of $0.16 \mathrm{~m}$ (collard root depth). Gravel and collard roots provide surface area for bacterial loading for nitrification [11]. And $12.7 \mathrm{~mm}$ plastic hoses were installed to direct effluent into the bio-filter and also convey treated water out of the bio-filter. Taps were also fitted on the inlet and exit hoses to regulate flow rate. 


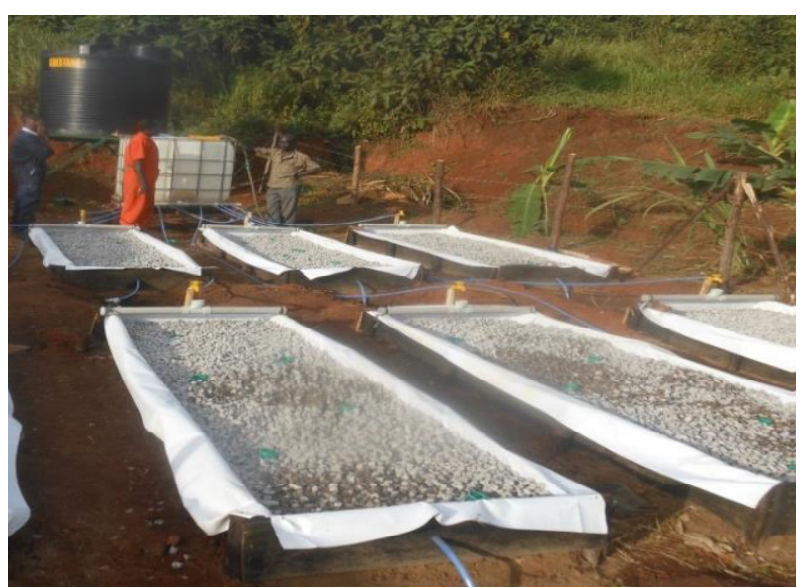

Fig. 3 Construction of collard based bio-filter.

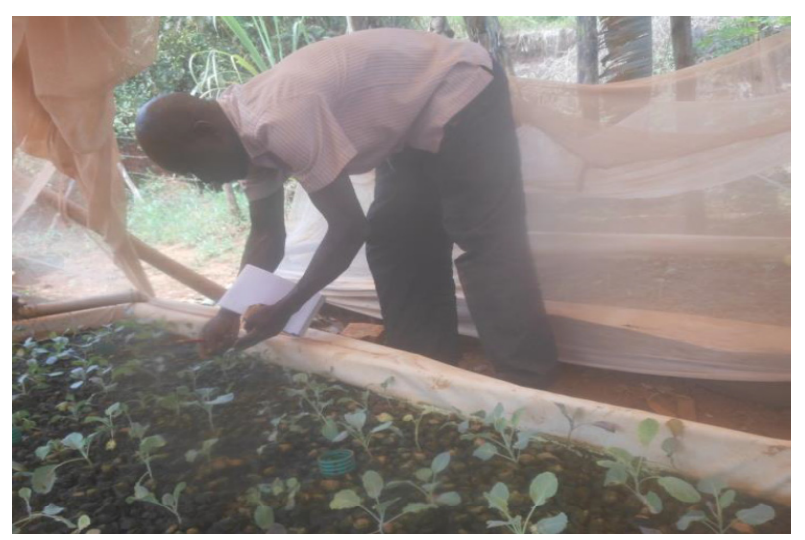

Fig. 4 Collards growing in the bio-filter.

Collard seedlings were transplanted in the bio-filter when 30 days old at 36 plants per $\mathrm{m}^{2}$ and covered with ordinary treated mosquito net to avoid attacks by insect pests (Fig. 4).

\subsubsection{Data Collection}

Field physical-chemical parameters that were measured from fish pond effluent in both vegetable based and gravel bio-filters included: ammonia $(\mathrm{mg} / \mathrm{L})$; nitrate $(\mathrm{mg} / \mathrm{L})$; dissolved oxygen $(\mathrm{mg} / \mathrm{L})$; temperature $\left({ }^{\circ} \mathrm{C}\right)$ and $\mathrm{pH}$. Measurements were done at various lengths: $\mathrm{L}_{1}, \mathrm{~L}_{2}, \mathrm{~L}_{3}$ and $\mathrm{L}_{4}$ during time range of 1-21 days, 22-42 days and 43-56 days of fish growth. Ammonia and nitrate concentrations were measured to assess the performance of collard based bio-filter, specifically to determine the extent to which ammonia and nitrate levels were reduced in the effluent since they are toxic to fish at concentrations greater than 0.3 $\mathrm{mg} / \mathrm{L}$ and $200 \mathrm{mg} / \mathrm{L}$ respectively. This was achieved by drawing effluent samples $(5 \mathrm{~mL})$ at every length from which ammonia and nitrate concentrations were measured. The measurements were done using LaMotte reagent test kits. The levels of dissolved oxygen, temperature and $\mathrm{pH}$ were measured using a digital multi parameter meter (DZB 712). This was done to determine whether the levels of dissolved oxygen, temperature and $\mathrm{pH}$ were favorable to support effective nitrification process in the bio-filter. According to Masser, et al. [12] dissolved oxygen, temperature and $\mathrm{pH}$ are major parameters that support effective nitrification. Measurements started 10 days after collards were transplanted in the bio-filter. It continued once in every seven days for a period of 56 days until collards reached maturity stage. At maturity, fibrous collard roots provide sufficient surface area for more bacterial loading hence better nitrification and also maximum nitrate uptake.

\subsubsection{Data Analysis}

The difference in mean ammonia and nitrate concentrations $(\mathrm{mg} / \mathrm{L})$ at various bio-filter lengths was analyzed using one-way analysis of variance in GenStat Discovery Edition 4 Software at 5\% $(p<0.05)$ significant level. The mean values of dissolved oxygen $(\mathrm{mg} / \mathrm{L})$, temperature $\left({ }^{\circ} \mathrm{C}\right)$ and $\mathrm{pH}$ at bio-filter lengths $\left(\mathrm{L}_{0}, \mathrm{~L}_{1}, \mathrm{~L}_{2}, \mathrm{~L}_{3}\right.$ and $\left.\mathrm{L}_{4}\right)$ were compared with recommended levels for effective nitrification by Masser, et al. [12].

\section{Results and Discussions}

3.1 Fish tank Effluent Quality along Bio-Filter Length

\subsubsection{Ammonia Concentration}

Table 1 presents the measured ammonia concentrations and removal efficiency at various lengths during time range of 1-21 days, 22-42 days and 43-56 days of fish growth in collard based bio-filtration system.

Ammonia concentrations in the collard based bio-filtration system were reduced from $99.1 \mathrm{mg} / \mathrm{L}$ at $\mathrm{L}_{0}$ to $6.3 \mathrm{mg} / \mathrm{L}$ at $\mathrm{L}_{4}$, thus resulting into increased 
Table 1 Ammonia concentrations and removal efficiency at various lengths in collard based bio-filter.

\begin{tabular}{lllllllllll}
\hline \multirow{2}{*}{$\begin{array}{l}\text { Time } \\
\text { (days) }\end{array}$} & \multicolumn{4}{c}{ Ammonia concentrations $(\mathrm{mg} / \mathrm{L})$} & \multicolumn{5}{c}{ Ammonia removal efficiency (\%) } \\
\cline { 2 - 10 } & $\begin{array}{l}\mathrm{L}_{0} \\
(0 \mathrm{~m})\end{array}$ & $\begin{array}{l}\mathrm{L}_{1} \\
(0.6 \mathrm{~m})\end{array}$ & $\begin{array}{l}\mathrm{L}_{2} \\
(1.2 \mathrm{~m})\end{array}$ & $\begin{array}{l}\mathrm{L}_{3} \\
(1.8 \mathrm{~m})\end{array}$ & $\begin{array}{l}\mathrm{L}_{4} \\
(2.4 \mathrm{~m})\end{array}$ & $\mathrm{L}_{1}$ & $\mathrm{~L}_{2}$ & $\mathrm{~L}_{3}$ & $\mathrm{~L}_{4}$ & \\
\hline $1-21$ & 100.2 & 77.0 & 54.2 & 28.7 & 7.9 & 23.1 & 45.9 & 71.4 & 92.1 & 55.6 \\
$22-42$ & 98.5 & 75.1 & 52.5 & 23.8 & 5.6 & 23.8 & 46.7 & 75.8 & 94.3 & 55.1 \\
$43-56$ & 98.4 & 74.0 & 51.4 & 20.8 & 5.3 & 24.8 & 47.8 & 78.9 & 94.6 & 55.1 \\
$\begin{array}{l}\text { Mean } \\
(\mathrm{mg} / \mathrm{L})\end{array}$ & $99.1 \pm 1.0$ & $75.4 \pm 1.6$ & $52.7 \pm 1.4$ & $24.4 \pm 4.0$ & $6.3 \pm 1.4$ & 23.9 & 46.8 & 75.4 & 93.7 & \\
Removal rate $\left(\mathrm{mg} \cdot \mathrm{L}^{-1} \cdot \mathrm{d}^{-1}\right)$ & 39.1 & 38.5 & 37.8 & 37.6 & & & & & \\
\hline
\end{tabular}

removal efficiency up to $93.7 \%$ at $\mathrm{L}_{4}$. This therefore, contributed to significant decrease $(p<0.05)$ in ammonia concentrations downstream bio-filter length. The significant decrease in ammonia concentrations at various bio-filter lengths was as a result of increasing HRT [13]. Increased HRT of effluent in the collard based bio-filter offered more time duration for nitrification process whereby more ammonia was oxidized to nitrate. As the residence time increased, fish effluent was subjected to more bacterial load which resulted into increased nitrification. In this study ammonia levels were reduced from 99.1 to 6.3 $\mathrm{mg} / \mathrm{L}$ (93.7\% removal efficiency) at $\mathrm{L}_{4}$. Comparative study by Sakuma, et al. [14] reported up to $99.9 \%$ ammonia removal efficiency in bio-filters. However, in this study, it was not achievable as the nitrifying bacteria became inefficient due to decline in $\mathrm{pH}$ levels which could not support effective nitrification i.e. 6.67, 6.35 and 6.06 at $\mathrm{L}_{2}, \mathrm{~L}_{3}$ and $\mathrm{L}_{4}$, respectively. This was linked to the experimental results of Masser, et al. [12] who showed nitrifying bacteria are most efficient within (7-8) $\mathrm{pH}$ range. The decline in $\mathrm{pH}$ was because bacterial nitrification produced acids and carbon-dioxide generated by fish and microorganisms reacted with water to form carbonic acid which drove the $\mathrm{pH}$ downwards [12]. Similarly the removal efficiency of ammonia was below $99.9 \%$ due to decline in dissolved oxygen levels beyond the recommended levels $\left(1.40,0.95\right.$ and $0.57 \mathrm{mg} / \mathrm{L}$ at $\mathrm{L}_{2}$, $\mathrm{L}_{3}$ and $\mathrm{L}_{4}$ ) respectively. The efficiency of nitrifying bacteria begins to decrease when dissolved oxygen levels decline below $2 \mathrm{mg} / \mathrm{L}$ because nitrification is oxygen consuming process [12]. Therefore beyond $\mathrm{L}_{4}$, the level of dissolved oxygen and $\mathrm{pH}$ were likely not to support any nitrification at all. Hence further increase in length would not yield any significant ammonia removal, hence appropriate length of collard based bio-filter would be $\mathrm{L}_{4}(2.4 \mathrm{~m})$.

Ammonia removal rate decreased significantly $(p<$ 0.05 ) from $39.1 \mathrm{mg} \cdot \mathrm{L}^{-1} \cdot \mathrm{d}^{-1}$ at $\mathrm{L}_{1}$ up to $37.8 \mathrm{mg} \cdot \mathrm{L}^{-1} \cdot \mathrm{d}^{-1}$ at $\mathrm{L}_{3}$ and beyond this the decrease was insignificant. The significant decrease in the rate of nitrification or rate of ammonia removal was attributed to the decrease in dissolved oxygen and $\mathrm{pH}$ levels which could not enable nitrifying bacteria to perform effectively downstream bio-filter length [14]. Mean ammonia concentrations during 1-21 days and 22-42 days were significantly different $(p<0.05)$, beyond which the difference is not significant $(p>0.05)$. The significant increase in the mean ammonia removal during 1-21 days and 22-42 days with collard growth was a result of extra gradual increase in surface area for more bacterial loading provided by the growth of collard roots [11, 15]. Therefore, the more the bacterial loading the higher the ammonia removal. Beyond day 42, increase in ammonia removal was insignificant due to limited root growth which could not continue to increase surface area for more bacterial loading. The collard roots could have been fully established. A comparison between collard based and GBFs showed significant $(p<0.05)$ ammonia removal in collard based bio-filter than GBF by $18.3 \%$. The higher ammonia removal in collard based bio-filter than gravel bio-filter was a result of increased surface 
area provided by the fibrous roots of collards. The increased surface area resulted into more bacterial loading leading to higher nitrification in collard based filter. This was in line with the findings of Brix [15] that macrophytes (water plants) with fibrous roots provide surface area for bacterial loading.

\subsubsection{Nitrate Concentration}

Table 2 presents the nitrate concentrations and removal efficiency at various bio-filter lengths during time range of 1-21 days, 22-42 days and 43-56 days of fish growth.

Nitrate concentrations in the collard based bio-filtration system were reduced from $11.8 \mathrm{mg} / \mathrm{L}$ at $\mathrm{L}_{0}$ to $0.1 \mathrm{mg} / \mathrm{L}$ at $\mathrm{L}_{4}$, thus resulting into increased removal efficiency up to $99.5 \%$ at $\mathrm{L}_{4}$. This has contributed to significant reductions $(p<0.05)$ in the mean nitrate concentrations at various bio-filter lengths. The significant decrease in nitrate concentrations at various bio-filter lengths downstream was due to increased residence time for nitrate absorption by both algae and collards.

The rate of nitrate removal was observed to decrease significantly $(p<0.05)$ from $7.8 \mathrm{mg} \cdot \mathrm{L}^{-1} \cdot \mathrm{d}^{-1}$ at $\mathrm{L}_{1}$ up to $4.9 \mathrm{mg} \cdot \mathrm{L}^{-1} \cdot \mathrm{d}^{-1}$ at $\mathrm{L}_{4}$ downstream. The decrease in the rate of nitrate removal was due to decrease in nitrate availability for plants downstream. Therefore this decrease in nitrate availability resulted into reduced level of nitrate uptake by plants downstream bio-filter length [16]. Mean nitrate concentrations during 1-21 days and 22-42 days were significantly different $(p<0.05)$, beyond which the difference is not significant $(p>0.05)$. The significant difference in nitrate removal during 1-21 days and
22-42 days of measurement was as a result of increased nitrate uptake with increase in plants (collard \& algae) growth. The 100\% nitrate removal efficiency at $\mathrm{L}_{4}$ during 22-42 and 43-56 days of measurement meant that both collards and algae had the potential to extract all the available nitrate in the effluent [17]. The insignificant difference in nitrate removal beyond 22-42 days was an indication that nitrate uptake by collards reduced, this was as a result of high competition for nitrate with algae [17]. Beyond days 22-42, algae concentration increased thus depleting available nitrate in the effluent. Higher algae concentration in the effluent increased their nutrient uptake capacity. Studies conducted by Mahapatra and Chanakya [16] revealed that algae has been used in wastewater treatment since they are efficient in absorbing nutrients. Therefore, collards were deprived of nitrate resulting into reduced nitrate uptake.

Significant difference $(p<0.05)$ was observed in nitrate removal between collard based and gravel bio-filters. Collard based filter yielded higher nitrate removal at $\mathrm{L}_{4}$ by $39.5 \%$ as compared to gravel filter. This gave an indication that at $\mathrm{L}_{4}$ in collard based bio-filter, $39.5 \%$ of the nitrate in the effluent was absorbed by collards.

3.1.3 Temperature, Dissolved Oxygen and $\mathrm{pH}$ of the Effluent

The mean values of effluent temperature, dissolved oxygen concentration and $\mathrm{pH}$ at various lengths $\left(\mathrm{L}_{0}\right.$, $\mathrm{L}_{1}, \mathrm{~L}_{2}, \mathrm{~L}_{3}$ and $\mathrm{L}_{4}$ ) in comparison with recommended safe levels for effective nitrification by Masser et al. [12] are presented in Table 3.

Table 2 Nitrate concentrations and removal efficiency at various lengths in collard based bio-filter

\begin{tabular}{lllllllllll}
\hline \multirow{2}{*}{$\begin{array}{l}\text { Time } \\
(\text { days })\end{array}$} & \multicolumn{4}{c}{ Ammonia concentrations $(\mathrm{mg} / \mathrm{L})$} & \multicolumn{5}{c}{ Nitrate removal efficiency $(\%)$} & Mean \\
\cline { 2 - 10 } & $\mathrm{L}_{0}$ & $\mathrm{~L}_{1}$ & $\mathrm{~L}_{2}$ & $\mathrm{~L}_{3}$ & $\mathrm{~L}_{4}$ & $\mathrm{~L}_{1}$ & $\mathrm{~L}_{2}$ & $\mathrm{~L}_{3}$ & $\mathrm{~L}_{4}$ & $(\mathrm{mg} / \mathrm{L})$ \\
\hline $1-21$ & 11.8 & 8.0 & 4.8 & 2.5 & 0.2 & 32.2 & 59.1 & 79.0 & 98.4 & 6.8 \\
$22-42$ & 11.8 & 6.9 & 2.9 & 0.9 & 0.0 & 41.9 & 75.3 & 92.0 & 100.0 & 5.6 \\
$43-56$ & 11.9 & 6.0 & 2.4 & 0.7 & 0.0 & 49.7 & 80.0 & 94.1 & 100.0 & 5.2 \\
Mean $(\mathrm{mg} / \mathrm{L})$ & $11.8 \pm 0.1$ & $6.9 \pm 1.0$ & $3.4 \pm 1.3$ & $1.4 \pm 1.0$ & $0.1 \pm 0.1$ & 41.3 & 71.5 & 88.4 & 99.5 & \\
Removal rate $\left(\mathrm{mg} \cdot \mathrm{L}^{-1} \cdot \mathrm{d}^{-1}\right)$ & 7.8 & 6.8 & 5.7 & 4.9 & & & & & \\
\hline
\end{tabular}


Table 3 Mean values of temperature, dissolved oxygen and pH downstream bio-filter length.

\begin{tabular}{lllllll}
\hline \multirow{2}{*}{ Parameter } & \multicolumn{5}{c}{ VBF lengths } & Safe levels \\
\cline { 2 - 7 } & $\mathrm{L}_{0}(0 \mathrm{~m})$ & $\mathrm{L}_{1}(0.6 \mathrm{~m})$ & $\mathrm{L}_{2}(1.2 \mathrm{~m})$ & $\mathrm{L}_{3}(1.8 \mathrm{~m})$ & $\mathrm{L}_{4}(2.4 \mathrm{~m})$ & $25-30$ \\
\hline Temperature $\left({ }^{\circ} \mathrm{C}\right)$ & 25.85 & 25.84 & 25.84 & 25.86 & 25.87 & $>2$ \\
Dissolved oxygen $(\mathrm{mg} / \mathrm{L})$ & 2.45 & 2.03 & 1.40 & 0.95 & 0.57 & $7-8$ \\
$\mathrm{pH}$ & 7.5 & 7.07 & 6.67 & 6.35 & 6.06 & 7 \\
\hline
\end{tabular}

Average effluent temperature downstream bio-filter length was within the recommended range, thus indicating that temperature was favorable for nitrification. It was further observed that dissolved oxygen concentration decreased significantly $(p<$ 0.05 ) below recommended level of $2 \mathrm{mg} / \mathrm{L}$ at $\mathrm{L}_{2}, \mathrm{~L}_{3}$ and $\mathrm{L}_{4}$ respectively. The decrease was attributed to high dissolved oxygen consumption by bacteria during nitrification process [14]. Similar, effluent $\mathrm{pH}$ decreased significantly $(p<0.05)$ beyond the recommended range of $7-8$ at $\mathrm{L}_{2}, \mathrm{~L}_{3}$ and $\mathrm{L}_{4}$. The decline in $\mathrm{pH}$ was due to bacterial nitrification which produced acids, also carbon-dioxide generated by fish and microorganisms reacted with water to form weak carbonic acid which drove the $\mathrm{pH}$ downwards [13]. Therefore, low levels of dissolved oxygen $(<2 \mathrm{mg} / \mathrm{L})$ and $\mathrm{pH}$ (and $<7$ ) respectively contributed to inefficiency of nitrifying bacteria leading to incomplete ammonia removal from 99.1 to $6.3 \mathrm{mg} / \mathrm{L}$ representing $93.7 \%$ ammonia removal efficiency at $\mathrm{L}_{4}$.

\section{Conclusion and Recommendations}

In this study, maximum ammonia and nitrate removal from fish tank effluent in collard based bio-filtration system was achieved at $\mathrm{L}_{4}(2.4 \mathrm{~m})$, hence the appropriate length for collard based bio-filter is $\mathrm{L}_{4}$. Collard based bio-filter has the potential to remove ammonia and nitrate up to $93.7 \%$ and $99.5 \%$ respectively under natural conditions (temperature, dissolved oxygen and $\mathrm{pH}$ ). Use of collards in bio-filters contributed up to $18.3 \%$ and $39.5 \%$ ammonia and nitrate removal efficiencies at $\mathrm{L}_{4}$ respectively.

Ammonia removal below $6.3 \mathrm{mg} / \mathrm{L}$ (93.7\%) was limited by dissolved oxygen and $\mathrm{pH}$ levels. Peri-urban fish farmers should therefore use low cost aerators and agricultural lime for complete ammonia removal. Treated water from collard based bio-filter is recommended for use by fish farmers who maintain ammonia in fish tanks up to $99.1 \mathrm{mg} / \mathrm{L}$. Further research is recommend to evaluate the performance of collard based bio-filter using aerator, agricultural lime and various indigenous vegetables.

\section{Acknowledgement}

The authors appreciate the financial support from Marketplace Agricultural Innovation Brazil which facilitated smooth implementation of the research Project ID 411.

\section{References}

[1] Blumenthal, U. J., Peasey, A., Ruiz-palacios, G., and Mara, P. D. D. 2000. Guidelines for Wastewater Reuse in Agriculture and Aquaculture: Recommended Revisions Based on New Research Evidence. WELL Study, Task No: 68 Part 1. https://pdfs.semanticscholar. org/872e/09b0067215029edea7ccedfd83f76c4a4d0c.pdf.

[2] Steicke, A. R., Jegatheesan, V., and Zeng, C. 2009. "Recirculating Aquaculture Systems." Water Wastewater Treat. Technol. Encylopardis of Life Support System. Oxford, UK.

[3] Hambrey, J. 2000. "Environmental Management of Aquaculture Development." INFOFISH Int. Kuala Lumpur 5: 25-9.

[4] Miller, D., and Semmens, K. 2002. "Waste Management in Aquaculture." Aquaculture Information Series. AQ02-1. Retrieved from http://aquaculture.ext.wvu. edu/r/download/43721.

[5] Aiveca, H. J. 2014. Masters thesis on Aquaponics and Its Potential Aquaculture Wastewater Treatment and Human Urine Treatment. Faculty of Science and Technology, New University of Lisbon, Portugal https://www.hemmaodlat.se/research/sanchez\%202014.

[6] Bhatnagar, A., and Devi, P. 2013. "Water Quality Guidelines for the Management of Pond Fish Culture." International Journal of Environmental Sciences 3 (6): 1980-2009. 
[7] Hochheimer, J. N., and Wheaton, F. 2000. "Biological Filters: Trickling and RBC Design." In Proceedings of the Second International Conference on Recirculating Aquaculture Roanoke, Virginia, pp. 291-318.

[8] Ngugi, C. C., Bowman, J. R., and Omolo, B. O. 2007. A New Guide to Fish Farming in Kenya. Aquaculture Collaborative Research Support Program.

[9] United States Environmental Protection Agency. 1988. "Design Manual: Constructed Wetlands and Aquatic Plant Systems for Municipal Wastewater Treatment." No. September, p. 92.

[10] Anish, T. B., and Kumar, G. A. 2012. "Design Approach for Sub-surface Flow Constructed Wetlands." Hydro Nepal 10: 42-7.

[11] Tousignant, E., Fankhauser, O., and Hurd, S. 1999. Guidance Manual for the Design, Construction and Operations of Constructed Wetlands for Rural Applications in Ontario. Research and Technology Transfer Group, Alfred College (University of Guelph) South Nation Conservation. p. 164.

[12] Masser, M. P., Rakocy, J., and Losordo, T. M. 1999.
"Recirculating Aquaculture Tank Production Systems: Management of Recirculating Systems." SRAC Publication, No. 452.

[13] Shahmansoury, M. R., Taghipour, H., Bina, B., and Movahedia, H. 2005. "Biological Removal of Ammonia from Contaminated Air Streams Using Biofiltration System.” Iran. J. Environ. Heal. Sci. Eng. 2 (3): 17-25.

[14] Sakuma, T., Jinsiriwanit, S., Hattori, T., and Deshusses, M. A. 2008. "Removal of Ammonia from Contaminated Air in a Biotrickling Filter-Denitrifying Bioreactor Combination System." Water Res. 42 (17): 4507-13.

[15] Brix, H. 1994. "Functions of Macrophytes in Constructed Wetlands." Water Science and Technology 29 (4): 71-8.

[16] Mahapatra, D. M., and Chanakya, H. N. 2013. "Treatment Efficacy of Algae-Based Sewage Treatment Plants." Environmental Monitoring and Assessment 185 (9): 7145-64.

[17] Neere, K. A. 2013. "Waste Water Treatment by Algae." In Proceedings of International Conference on Energy and Environment 2013 (ICEE 2013), 12th to 14th December 2013, pp. 286-93. 